\title{
Complement-fixing activity of rheumatoid synovial fluid
}

\author{
A. S. TOWNES* AND R. L. MARCUS $\dagger$ \\ From the Connective Tissue Division of the Department of Medicine, Johns Hopkins University School of \\ Medicine, the Department of Medicine, Baltimore City Hospitals, and the O'Neill Research Laboratories of the \\ Good Samaritan Hospital
}

Haemolytic complement activity has been shown to be reduced in synovial fluid of patients with rheumatoid arthritis as compared with patients with inflammatory effusions of similar protein content due to other causes (Hedberg, 1963; Pekin and Zvaifler, 1964; Fostiropoulous, Austen, and Bloch, 1965; Peltier, Coste, and Delbarre, 1966; Townes and Sowa, 1970). Anticomplementary activity was not observed, however, except as subsequently reported by Hedberg (1967).

Using unheated synovial fluid and a period of incubation with a complement source, we have demonstrated anticomplementary or complementfixing activity in a significant number of rheumatoid synovial effusions. This activity demonstrates a pattern of complement-component fixation identical to that of antigen-antibody complexes or gamma globulin aggregates. In order clearly to differentiate this activity from poorly defined anticomplementary activities associated with contaminated, aged, or extensively manipulated biological fluids, we refer to this activity as complement-fixing.

The frequency, specificity, and stability characteristics of this complement-fixing activity, are presented below with preliminary observations on its clinical correlates.

\section{Material and methods}

COLLECTION AND PROCESSING OF SYNOVIAL FLUID Synovial fluid was obtained by needle aspiration from patients with synovial effusions due to various causes, allowed to stand at room temperature for $30 \mathrm{~min}$., centrifuged at $15,000 \mathrm{G}$ for $15 \mathrm{~min}$. at $4^{\circ} \mathrm{C}$. to remove cells, clots, and debris, quick frozen in small aliquots, and stored at $-70^{\circ} \mathrm{C}$. until used. Patients with rheumatoid arthritis met the ARA criteria (Ropes, Bennett, Cobb, Jacox, and Jessar, 1959) for definite or classical disease. Diagnosis in other patients was based on clinical findings detailed elsewhere (Townes and Sowa, 1970).

\section{COMPLEMENT}

Fresh frozen guinea-pig serum was obtained from Suburban Laboratories, Silver Spring, Maryland. Human serum routinely used for complement was obtained from a pool of blood bank donors, or occasionally from individual donors.

TESTS FOR COMPLEMENT-FIXING ACTIVITY Complement was diluted in isotonic veronal-buffered saline pH 7.4 containing 0.1 per cent. gelatin, $0.00015 \mathrm{M}$ calcium chloride, and 0.001 $\mathrm{M}$ magnesium chloride (Kabat and Mayer, 1961) (hereafter abbreviated GVB) so that approximately 7 to $8 \mathbf{C H}_{50}$ units of complement were available (before incubation) in $2.4 \mathrm{ml}$. Synovial fluid samples were thawed rapidly at $37^{\circ} \mathrm{C}$. and $0.1 \mathrm{ml}$. was added to $2.4 \mathrm{ml}$. complement dilution and incubated at $37^{\circ} \mathrm{C}$. for $60 \mathrm{~min}$.

$10 \mathrm{ml}$. of cold GVB was then added to the reaction mixture, which was titrated in the usual manner for residual complement activity with sensitized sheep erythrocytes (EA) ${ }^{1}$ in a total volume of $7.5 \mathrm{ml}$. with incubation for $1 \mathrm{hr}$ at $37^{\circ} \mathrm{C}$. (Kabat and Mayer, 1961). Complement fixation is expressed as the percentage of the available complement inactivated by $0.1 \mathrm{ml}$. synovial fluid. This volume of synovial fluid was chosen for routine testing since the resultant concentration (1/25 in the reaction mixture) minimized the contribution of complement activity from

\footnotetext{
The nomenclature used conforms to that published in the Bulletin of the World Health Organization (1968), 39, 935. Sheep erythrocytes (E), sensitized with rabbit antibody (A), react with complement (C), (E), sensitized with rabbit antibody (A), react with complement (C), followed by those components which have interacted designated by number, the entire sequence EAC $1,4,2,3,5,6,7,8,9$ being necessary
for haemolysis. Total haemolytic complement in 50 per cent. haemolytic units is designated $\mathrm{CH}_{50}$ and individual components $\mathrm{C1}, \mathrm{C4}$, etc. The 'bar' in $\mathrm{C} T$, or $\mathrm{C} \overline{4}, \overline{2}$, indicates an enzymically active component or complex.
}

Accepted for publication January 10, 1972. A preliminary report of a portion of this work was presented at a meeting of the American Rheu-

matism Association. See abstract in Arthr. and Rheum (1966) 9, 878 , the Good Samaritan Hospital.

* Associate Professor of Medicine, Johns Hopkins University School of Medicine. New Address: Deparment of Rheumatology, University of Tennessee, 858 Madison Avenue, Memphis, Tennessee 38103, U.S.A.

$\uparrow$ Assistant Professor of Medicine, Johns Hopkins University School of Medicine. Trainee USPHS Training Grant in Arthritis 5 TO1 AM 05033 and subsequently recipient USPHS Special Fellowship (FO3 AM 18178).

Reprint requests to Dr Robert Marcus, O'Neill Laborarories, Good Samaritan Hospital, Baltimore, Md 21212 U.S.A. 
unheated synovial fluid, yet allowed detection of complement-fixing activity in most fluids.

In addition to synovial fluid, unheated sera from fifteen of the rheumatoid and ten nonrheumatoid patients were similarly tested at varying dilutions from $1 / 25$ to $1 / 250$.

After subsequent discovery that complement-fixing activity in rheumatoid synovial fluid is cryoprecipitable, the collection of fluids and assay for activity were modified (Marcus and Townes, 1971) to allow the detection of complement fixation by cryoprecipitates. Since washing of cryoprecipitates resulted in considerable loss of complement-fixing activity (Marcus and Townes, 1971), cryoprecipitates were simply centrifuged and re-suspended in GVB in a volume equivalent to the amount of synovial fluid used to prepare the cryoprecipitate, or one fourth of that volume. $0.1 \mathrm{ml}$. of this re-suspended cryoprecipitate was then added immediately to the complement dilution and assayed for complement-fixing activity as described above. Nonrheumatoid synovial fluid cryoprecipitates were similarly tested.

\section{REPRODUCIBILITY OF COMPLEMENT FIXATION} Duplicate determinations on aliquots of the same sample indicated a precision of \pm 5 per cent. of $\mathrm{CH}_{50}$ units fixed. Further to test reproducibility, twelve separate determinations on different days were performed with freshlythawed aliquots of three synovial fluids which demonstrated strong, weak, and no complement fixation. Mean complement fixation of $51 \cdot 7$ per cent. $\pm 4.3,14$ per cent. $\pm 5 \cdot 8$, and 0 was obtained for the three samples respectively. Cryoprecipitates from these fluids similarly tested demonstrated complement fixation of $44 \cdot 3 \pm 4 \cdot 8,18 \cdot 2 \pm$ 3.9 , and 0 .

\section{FIXATION OF COMPLEMENT COMPONENTS}

In studies of complement component fixation, a reaction mixture identical to that for whole complement fixation was used, with the exception that after initial incubation at $37^{\circ} \mathrm{C}$. for $60 \mathrm{~min}$., the mixture was appropriately diluted and analysed for $\mathrm{C} 1, \mathrm{C} 4$, and $\mathrm{C} 2$, using sensitized sheep erythrocyte-guinea-pig complement intermediates. C1 was measured with EAC4 prepared by the method of Borsos and Rapp (1967). Functionally pure guinea-pig C2 was used (Borsos, Rapp, and Cook, 1961a) and guinea-pig serum diluted $1 / 37.5$ in $\mathrm{pH} 7.4$ veronal- buffered saline, containing $0.01 \mathrm{M}$ trisodium ethylenediaminetetraacetate (EDTA), provided the additional components necessary for haemolysis. $\mathrm{C} 2$ was measured as previously described, using EACI,4 (Townes and Stewart, 1965). The classical third component activity representing the total activity of $\mathrm{C} 3, \mathrm{C} 5, \mathrm{C} 6, \mathrm{C} 7, \mathrm{C} 8$, and C9 was titrated as follows:

To an additional aliquot of the synovial fluid complement reaction mixture, after the initial 60-min. incubation, $0 \cdot 1 \mathrm{M}$ EDTA, $\mathrm{pH} 7 \cdot 4$, was added to a final concentration of $0.01 \mathrm{M}$ and the capacity of this mixture to haemolyse EAC 1,4,2 was tested. Comparison was made with a complement control treated in similar fashion.

In tests for consumption or fixation of isolated or erythrocyte-bound complement components, guinea-pig C2, EACI, 4 and EAC4 were prepared as noted above. Guinea-pig C1 was prepared by the method of Nelson, Jensen, Gigli, and Tamura (1966); human C4 was prepared by the method of Muller-Eberhard and Biro (1964); and EAC4, 2 was prepared by the method of Borsos, Rapp, and Mayer (1961b). In these assays utilizing EACI,4, EAC4, and EAC4, 2, suspensions possessing limited reactive sites were prepared $(Z$ value equal to approximately 1 in control tube following incubation). The use of such preparations was necessary to detect any minimal loss of reactive sites.

\section{OTHER PROCEDURES}

Complement titres of synovial fluid were determined as previously described (Townes and Sowa, 1970). F II latex-fixation tests were performed using the method of Singer and Plotz (1956), beginning with a $1 / 20$ dilution of whole serum, or of synovial fluid previously digested with 10 units/ml. bovine testicular hyaluronidase (Nutritional Biochemicals Corporation of Cleveland, Ohio). Pancreatic deoxyribonuclease IX crystallized was obtained from Mann Laboratories (New York, N.Y.)

\section{Results}

\section{Complement fixation by synovial fluids}

The properties of rheumatoid synovial fluid complement-fixing activity, using human complement as a complement source, are presented in Table I.

\section{Table I Properties of rheumatoid synovial fluid complement-fixing activity}

\section{Property tested}

(1) Stability (a) at $37^{\circ} \mathrm{C}$. for $24 \mathrm{hrs}$

(b) at $0^{\circ} \mathrm{C}$. for $24 \mathrm{hrs}$

(c) after freezing and thawing once

(d) after heating to $56^{\circ} \mathrm{C}$. for $30 \mathrm{~min}$

(e) after storage at $-70^{\circ} \mathrm{C}$. up to $6 \mathrm{mths}$

(2) Dialysis, $\mathrm{pH}$ against isotonic neutral $\mathrm{pH}$ buffer against acetate buffer $\mathrm{pH} 3.5$ against carbonate buffer $\mathrm{pH} 9.6$

(3) Enzymatic digestion: Hyaluronidase (bovine testicular) 10 units/ ml. for $2 \mathrm{hrs}$

Deoxyribonuclease I 480 units $/ \mathrm{ml}$. for $4 \mathrm{hrs}$ $\left(0.001 \mathrm{M} \mathrm{MgSO}_{4}\right)$

(4) Effect of EDTA (final concentration of 0.01 M, pH 7.4)
Change in activity

None

Slight increase

None

25 to 60 per cent. decrease

None

None

90 per cent. decrease

80 per cent. decrease

None

None

100 per cent. decrease (reversible by dialysis 
Early in the course of our studies, to rule out the possibility that processing played a role in the generation of complement-fixing activity, arthrocentesis was performed in the laboratory, and within seconds, the uncentrifuged fluid was tested. This fluid showed a complement titre of $3 \mathrm{CH}_{50} / \mathrm{ml}$. and fixed 46 per cent. of the complement in the assay for complement-fixing activity. Tests on the same fluid after the usual processing, freezing, and thawing, indicated a complement titre of $1.8 \mathrm{CH}_{50} / \mathrm{ml}$. and 39 per cent. complement fixation.

The incidence of complement-fixing activity in rheumatoid and nonrheumatoid synovial fluids using guinea-pig or human complement is shown in Table II. The high incidence of this activity in rheumatoid fluid is apparent, while with rare exception such activity was absent in nonrheumatoid fluids. The percentage of available complement fixed by rheumatoid fluids varied from 5 to 75 per cent. The one nonrheumatoid fluid which demonstrated complement-fixing activity ( 8 per cent. complement fixation) was from a patient with systemic lupus erythematosus who had a rheumatoid-like arthritis and a negative latex text.

All the fluids tested with guinea-pig complement and summarized in Table II were tested also with human complement. Only eighteen of the 24 fluids which demonstrated fixation with guinea-pig complement also fixed human complement. An adequate explanation for the higher incidence of complement fixation by rheumatoid synovial fluid with guinea-pig complement as compared to human complement is not currently possible. Although none of the nonrheumatoid fluids tested fixed guinea-pig complement in the conditions of these experiments, we have previously noted an anticomplementary property of unheated normal human serum (Townes and Stewart, 1965) with guinea-pig complement, and have again encountered this phenomenon during the course of the present studies at higher dilutions of serum or synovial fluid. Therefore, to exclude this possibly non-specific effect, further studies were carried out with human complement.

The difference in the incidence of complementfixing activity in seropositive (36/54) as contrasted with seronegative cases $(2 / 16)$ as shown in Table II is statistically highly significant $(P<0.001)$.

The relationship between synovial fluid concentration and magnitude of complement fixation using unheated rheumatoid fluid and autologous and homologous complement is presented in Fig. 1 (overleaf).

Complement fixation occurred equally well with both complement sources. The significance of the slight decrease in complement fixation using autologous serum as a complement source is not known; but this was a consistent finding with synovial fluid from three rheumatoid patients tested in this manner. Although not apparent in Fig. 1, some unheated synovial fluids, especially those with normal complement values, demonstrated a procomplementary effect at the higher concentrations.

\section{Kinetics of complement fixation by rheumatoid synovial fluid}

Synovial fluid $1.5 \mathrm{ml}$. was incubated at $37^{\circ} \mathrm{C}$. with $36 \mathrm{ml}$. of $1 / 8$ dilution of human complement, and aliquots were titrated for residual complement at the times indicated in Fig. 2 (overleaf). From comparison with a control mixture containing complement alone, the percentage of available complement fixed was calculated. The results (Fig. 2) explain why anti-

Table II Incidence of complement-fixing activity in whole synovial fluid

\begin{tabular}{|c|c|c|c|c|}
\hline \multirow{2}{*}{\multicolumn{2}{|c|}{ Complement }} & \multirow[t]{2}{*}{ No. of patients tested } & \multicolumn{2}{|c|}{$\begin{array}{l}\text { Patients with complement-fixing } \\
\text { activity }\end{array}$} \\
\hline & & & No. & Per cent. \\
\hline \multicolumn{2}{|c|}{$\begin{aligned} & \text { Guinea-pig } \text { Rheumatoid } \\
& \text { Nonrheumatoid }\end{aligned}$} & $\begin{array}{l}31 \\
20\end{array}$ & $\begin{array}{r}24 \\
0\end{array}$ & 77 \\
\hline \multirow[t]{2}{*}{ Human Rheumatoid } & $\begin{array}{l}\text { Seropositive } \\
\text { Seronegative }\end{array}$ & $\begin{array}{l}54 \\
16\end{array}$ & $\begin{array}{r}36 \\
2\end{array}$ & $\begin{array}{l}67 \\
12 \cdot 5\end{array}$ \\
\hline & Total & 70 & 38 & 54 \\
\hline \multirow[t]{2}{*}{ Nonrheumatoid } & $\begin{array}{l}\text { Degenerative } \\
\text { Gout } \\
\text { Pseudogout } \\
\text { Infection } \\
\text { Acute polyarthritis } \\
\text { Reiter's syndrome } \\
\text { Psoriatic arthritis } \\
\text { Systemic lupus erythematosus }\end{array}$ & $\begin{array}{r}14 \\
13 \\
5 \\
7 \\
7 \\
2 \\
3 \\
4\end{array}$ & $\begin{array}{l}0 \\
0 \\
0 \\
0 \\
0 \\
0 \\
0 \\
1\end{array}$ & \\
\hline & Total & 55 & 1 & $1 \cdot 8$ \\
\hline
\end{tabular}




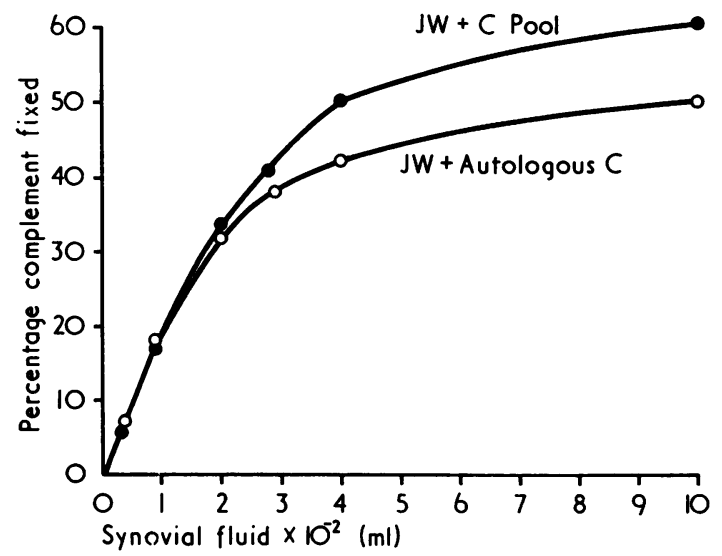

FIG. 1 Complement fixation by a rheumatoid synovial fluid (Patient J.W.), using autologous or pooled human serum as a complement source

complementary activity was not detected in rheumatoid synovial fluid in previous studies in which a period of incubation of synovial fluid with the complement source, before the addition of EA was not used (Pekin and Zvaifler, 1964; Fostiropoulous and others, 1965).

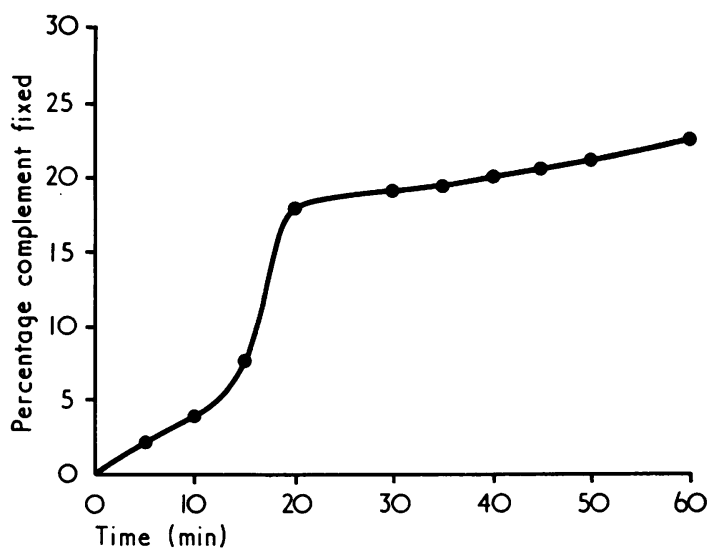

FIG. 2 Time course of complement fixation by a rheumatoid synovial fuid (Patient M.D. $1 / 257 \mathrm{CH}_{50}$ Human C)

Profile of complement component fixation using whole complement

Synovial fluid which fixed 53 per cent. of the total haemolytic complement, fixed 64 per cent. of $\mathrm{C1}$, 84 per cent. of $\mathrm{C} 4,82$ per cent. of $\mathrm{C} 2$, and 19 per cent. of components $(\mathrm{C} 3, \mathrm{C} 5, \mathrm{C} 6, \mathrm{C} 7, \mathrm{C} 8$, and $\mathrm{C} 9$ ) measured as a total activity with EDTA. Both the pattern of component fixation and the time course of complement fixation noted above are similar to that observed with immune aggregates.

Tests for consumption of cell-bound and isolated complement components

Heated rheumatoid synovial fluid $\left(56^{\circ} \mathrm{C} ., 30 \mathrm{~min}\right.$.) was used in these studies to avoid interference from endogenous complement components. 0.2-ml. aliquots of this fluid (from Patient G.H.) were added to suspensions of the cell intermediates EAC1,4, EAC4, or EAC4, 2, and the mixtures were incubated at $37^{\circ} \mathrm{C}$. for $30 \mathrm{~min}$., with intermittent agitation. Appropriate controls without synovial fluid were included. After incubation, the cell intermediates were centrifuged, the supernatant fluids aspirated, the cells re-suspended in the appropriate buffer, and the remaining complement components added in appropriate sequence to produce immune haemolysis. No inhibition or destruction of EAC4 or EAC4,2 by heated synovial fluid was observed. In contrast, 43 per cent. loss of $\mathrm{CI}$ sites from EACI, 4 was noted, consistent with the transfer and fixation of $\mathrm{Cl}$ by the rheumatoid synovial fluid. In a parallel assay, $0 \cdot 2 \mathrm{ml}$. of this heated synovial fluid fixed 34 per cent. of seven whole $\mathrm{CH}_{50}$ units.

Similarly, after incubation $\left(37^{\circ} \mathrm{C} ., 30 \mathrm{~min}\right.$.) of $0 \cdot 2-\mathrm{ml}$. aliquots of heated rheumatoid synovial fluid with preparations of C1, C4, or C2; fixation only of CI was observed ( 98 per cent. of 12,660 units).

Correlation of complement-fixing activity with complement titre

In Fig. 3 the percentage of complement fixed by 107 samples of synovial fluid from seventy patients with rheumatoid arthritis is plotted as a function of the complement titre in the same sample. Although not all fluids with a low complement titre had demonstrable anticomplementary activity, it is clear from the graph that the synovial fluids exhibiting strong complement-fixing activity had complement titres of $<10 \mathrm{CH}_{50} / \mathrm{ml}$, , and frequently $<5 \mathrm{CH}_{50} / \mathrm{ml}$. Of

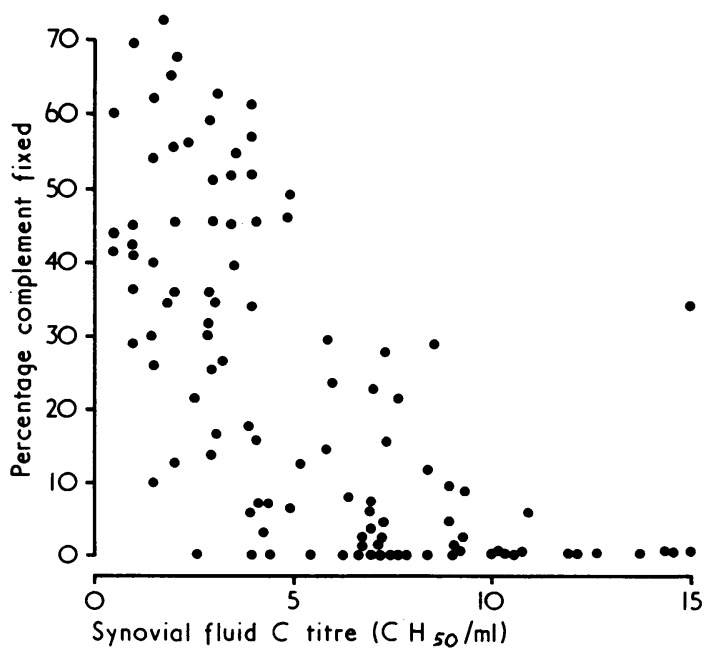

FIG. 3 Percentage complement fixation by 107 samples of rheumatoid synovial fluid plotted as a function of the haemolytic complement titre of that fluid 
note is the point indicating a complement titre of $15 \mathrm{Ch}_{50} / \mathrm{ml}$. and complement fixation of 35 per cent. from a patient with a superimposed acute pyogenic arthritis. After resolution of the infection, subsequent samples of synovial fluid had complement values of $<5 \mathrm{CH}_{50} / \mathrm{ml}$., and complement-fixing activity ranging from 45 to 65 per cent. This response is notably similar to that previously reported in a patient with systemic lupus whose depressed serum complement titre rose in response to a complicating bacterial infection (Townes, Stewart, and Osler, 1963).

\section{Correlation of complement-fixing activity with clinical} findings

Table III summarizes the clinical features of patients with rheumatoid arthritis in whom complementfixing activity was demonstrable in whole synovial fluid. A high percentage of male patients had synovial fluid complement-fixing activity. Furthermore, patients with this activity tended to be older, and had both a higher incidence of subcutaneous nodules and disease of somewhat longer duration and greater severity than patients without this activity.

Serial specimens from a single joint were not available in enough patients over a sufficient length of time to draw firm conclusions about the relationship to disease activity. When complement-fixing activity was present in one sample, it was also found in subsequent samples from the same patient. The greatest complement-fixing activity was found in patients with chronically active destructive synovitis rather than in patients with more acute intermittent effusions. Significant activity, however, was present in a few patients with effusions of less than 1 week's duration, and within 2 months of onset of disease. At least two patients with partial remissions induced by gold therapy had a decrease in complementfixing activity concomitant with clinical improvement. In another patient complement-fixing activity was initially demonstrable only in the cryoprecipitates; however, complement-fixing activity demonstrable in whole fluid appeared as the disease in that joint became progressively worse over a 6-month period.

\section{Correlation of complement-fixing activity with latex} titre

Correlation of synovial fluid complement-fixing activity with serum latex titre is presented in Fig. 4 (overleaf).

Although complement-fixing activity was present in only two patients with negative latex tests, there was no significant correlation between the percentage of complement fixed and the serum latex titre. In addition, latex titres in synovial fluid were obtained in fiftynine of the seventy patients. Tests were negative in the synovial fluid of all patients with negative serum titres. Synovial fluid titres tended to be lower than those in serum, and were negative in four patients with positive serum tests. Again, there was no significant correlation of complementfixing activity with latex titre in synovial fluid, although most patients with high titres had some complement-fixing activity.

Table III Correlation of rheumatoid synovial fluid complement-fixing activity with clinical features

\begin{tabular}{|c|c|c|}
\hline Patients & $\begin{array}{l}\text { With complement-fixing } \\
\text { activity }\end{array}$ & $\begin{array}{l}\text { Without complement-fixing } \\
\text { activity }\end{array}$ \\
\hline Total & 38 & 32 \\
\hline $\begin{array}{l}\text { Sex Male } \\
\text { Female }\end{array}$ & $\begin{array}{l}20 \\
18\end{array}$ & $\begin{array}{r}9 \\
23\end{array}$ \\
\hline Age (yrs) $\begin{array}{r}20-40 \\
40-60 \\
>60\end{array}$ & $\begin{array}{r}5 \\
11 \\
22\end{array}$ & $\begin{array}{r}13 \\
13 \\
6\end{array}$ \\
\hline Subcutaneous nodules & 28 & 9 \\
\hline $\begin{array}{ll}\text { Duration of disease (yrs) } & 1-5 \\
& 5-10 \\
& >10\end{array}$ & $\begin{array}{r}5 \\
11 \\
22\end{array}$ & $\begin{array}{r}7 \\
15 \\
10\end{array}$ \\
\hline ARA criteria $\begin{array}{r}\text { Classical } \\
\text { Definite }\end{array}$ & $\begin{array}{l}28 \\
10\end{array}$ & $\begin{array}{l}18 \\
14\end{array}$ \\
\hline $\begin{array}{rr}\text { Stage disease } & \text { II } \\
\text { II } \\
\text { III } \\
\text { IV }\end{array}$ & $\begin{array}{r}3 \\
6 \\
25 \\
4\end{array}$ & $\begin{array}{r}5 \\
8 \\
18 \\
1\end{array}$ \\
\hline Functional class $\begin{array}{r}\text { I } \\
\text { II } \\
\text { III } \\
\text { IV }\end{array}$ & $\begin{array}{r}0 \\
17 \\
16 \\
5\end{array}$ & $\begin{array}{r}1 \\
24 \\
6 \\
1 \\
\end{array}$ \\
\hline
\end{tabular}




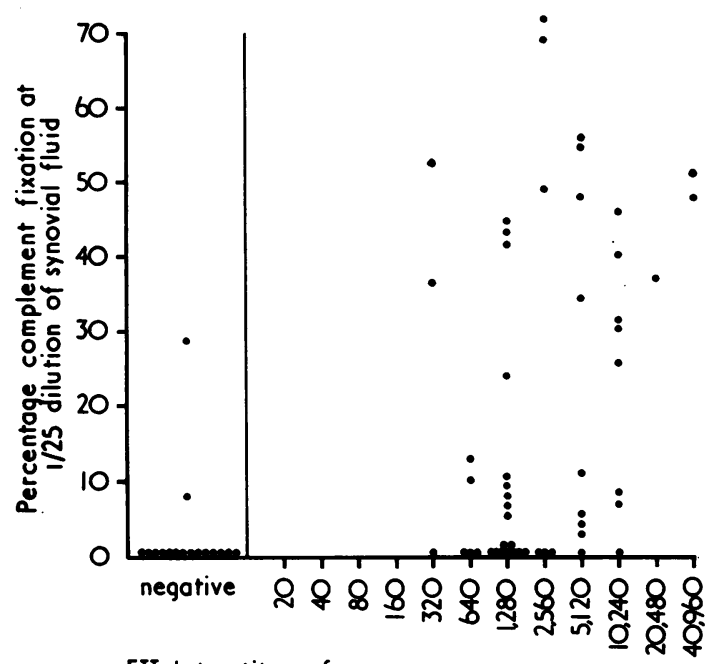

FII latex titre of serum

FIG. 4 The correlation of serum latex titre with synovial fluid complement-fixing activity in 69 patients with rheumatoid arthritis. Minus sign indicates no agglutination at a dilution of $1 / 20$.

Complement fixation by synovial fluid cryoprecipitates The discovery that a considerable portion of complement-fixing activity in rheumatoid synovial fluids is cryoprecipitable (Marcus and Townes, 1971) provided us with a simple method of isolating this activity from contaminating complement components in whole synovial fluid. We therefore re-examined all the synovial fluid specimens which had been appropriately collected to exclude loss of cold precipitable material for complement fixation by cryoprecipitates. The results are summarized in Table IV.

Complement-fixing cryoprecipitates were found in all the rheumatoid synovial fluids in which complement fixation was demonstrated with unheated whole fluid. Complement fixation by the cryoprecipitates ranged from 20 to 100 per cent. of that of the unheated whole synovial fluid at the same concentration. In addition, complement-fixing activity was demonstrated in many cryoprecipitates from fluids in which none was detected with whole synovial fluid. In general, less than 20 per cent. of the available complement was fixed by these cryoprecipitates, and in six fluids, activity was present only when four times concentrated cryoprecipitate was used. Thus, 35 of the 36 fluids from patients with seropositive rheumatoid arthritis and nine of thirteen fluids from patients with seronegative disease showed some complement-fixing activity in the cryoprecipitates. The difference in the frequency of complementfixing cryoprecipitates in seropositive as compared with seronegative cases is still statistically significant $(P<0.02)$.

Nonrheumatoid synovial fluid cryoprecipitates failed to show complement-fixing activity except for small amounts in three fluids, two from patients with systemic lupus erythematosus and one from a patient with pneumococcal pyarthrosis. In nonrheumatoid cryoprecipitates, unlike the six rheumatoid cryoprecipitates noted above, the incidence of complement fixation was unaltered by the use of four times concentrated cryoprecipitates in the test system.

Complement-fixing activity and cryoproteins in rheumatoid serum

None of fifteen serum specimens tested had complement-fixing activity demonstrable in unheated whole serum at dilutions of $1 / 25$ to $1 / 250$. However small amounts of cryoprecipitable protein were present in a high percentage of rheumatoid sera. Complement-fixing activity was detected in these re-suspended unwashed cryoprecipitates, but in no instance did the complement-fixing activity per $\mathrm{ml}$. serum approach the level found in the synovial fluid cryoprecipitate of the same patient. The associated complement-fixing activity of rheumatoid serum cryoprotein, was generally lost with washing. The immunoglobulins present in those serum cryoproteins which possessed sufficient material for analysis after washing were either IgG alone or mixed IgG and IgM.

\section{Discussion}

The demonstration of reduced complement in synovial fluid in rheumatoid arthritis despite normal or increased serum levels (Pekin and Zvaifler, 1964; Fostiropoulous and others, 1965; Hedberg, 1967;

Table IV Complement-fixing activity in synovial fluid and isolated synovial fuid cryoprecipitates

\begin{tabular}{|c|c|c|c|c|c|c|}
\hline \multirow{2}{*}{\multicolumn{2}{|c|}{ No. of patients }} & \multirow[t]{2}{*}{ Total tested } & \multicolumn{2}{|c|}{$\begin{array}{l}\text { Demonstrating complement } \\
\text { fixation using whole fluid }\end{array}$} & \multicolumn{2}{|c|}{$\begin{array}{l}\text { With complement-fixing } \\
\text { cryoprecipitates }\end{array}$} \\
\hline & & & No. & Per cent. & No. & Per cent. \\
\hline \multirow[t]{2}{*}{ Rheumatoid } & $\begin{array}{l}\text { Seropositive } \\
\text { Seronegative }\end{array}$ & $\begin{array}{l}36 \\
13\end{array}$ & $\begin{array}{r}23 \\
2\end{array}$ & $\begin{array}{l}64 \\
15\end{array}$ & $\begin{array}{r}35 \\
9\end{array}$ & $\begin{array}{l}97 \\
69\end{array}$ \\
\hline & Total & $\overline{49}$ & $\overline{25}$ & $\overline{51}$ & $\overline{44}$ & $\overline{90}$ \\
\hline \multicolumn{2}{|c|}{ Nonrheumatoid } & 35 & 1 & 3 & 3 & 9 \\
\hline
\end{tabular}


1967; Townes and Sowa, 1970) suggested the occurrence of an immune reaction within the synovium. Further evidence of this reaction has been the finding of deposits of gamma globulin (Kaplan, 1963) and gamma globulin and complement within the synovium (Fish, Michael, Gewurz, and Good, 1966; Rodman, Williams, Bilka, and Müller-Eberhard, 1967) and within synovial leucocytes (Rawson, Abelson, and Hollander, 1965; Vaughan, Barnett, Sobel, and Jacox, R. F., 1968a; Vaughan, Jacox, and Noell, 1968b).

The studies presented here extend these observations with the identification of a complement-fixing activity in rheumatoid synovial fluid. The demonstration that heated rheumatoid synovial fluid consumes $\mathrm{C1}, \mathrm{C} 4, \mathrm{C} 2$, and classical C3 when incubated with whole complement, but only $\mathrm{C} 1$ when exposed to isolated components or cell intermediates, effectively excludes the presence of a non-specific protease or of specific component inhibitors as being responsible for complement fixation. These findings implicate specific consumption of complement beginning with C1. Since this complement-fixing activity is present at $37^{\circ} \mathrm{C}$. immediately after aspiration. it is not likely to be an artefact in vitro.

The inverse correlation of magnitude of complement fixation by rheumatoid synovial fluid and synovial fluid $\mathrm{CH}_{50}$ titre (Fig. 3) suggests a causal relationship. The pattern of reduction in specific components of complement (Fostiropoulous and others, 1965; Ruddy, Britton, Schur, and Austen, 1969; Ruddy and Austen, 1970; Townes and Sowa, 1970) also is consistent with the conclusion that activation and depletion of synovial complement occurs in rheumatoid arthritis. The potential for reaction in vivo is further indicated by the reaction with autologous complement demonstrated here.

The strong association of complement-fixing activity in synovial fluid with the rheumatoid process is emphasized by its virtual absence from nonrheumatoid effusions, including a few patients with pseudogout and infection in whom the total $\mathrm{CH}_{50}$ synovial fluid levels were reduced. The more sensitive detection of complement-fixing activity in synovial fluid using cryoprecipitates indicates that this reaction occurs to some extent in virtually all patients with seropositive rheumatoid disease and also in a significant number of seronegative patients (Table III). Since nonrheumatoid cryoprecipitates, with rare exceptions, again fail to demonstrate this activity, these findings warrant the consideration of a specific role for this activity in the rheumatoid inflammatory process.

Identification of the material responsible for complement fixation has been facilitated by the discovery that a significant portion of this activity is cryoprecipitable. Analysis of rheumatoid synovial cryoprecipitates has demonstrated that they contain a mixture of immunoglobulins, bound complement components, fibrinogen, and in some instances DNA (Barnett, Bluestone, Gracchiolo, Goldberg, Kantor, and McIntosh, 1970; Marcus and Townes, 1971). The complement-fixing activity is greatest in heavy sedimenting density gradient fractions which contain IgG alone or mixed IgG and IgM, and is indicative of the presence of immunoglobulin aggregates (Marcus and Townes, 1971).

Immunoglobulin aggregates have previously been found in rheumatoid synovial fluid by Hannestad (1967); and Baumal and Broder (1968) have described a biologically active factor in the serum and synovial fluid of patients with rheumatoid arthritis which they attribute to soluble antigen-antibody complexes. Winchester, Agnello, and Kunkel (1969) have reported IgG globulin aggregates in rheumatoid synovial fluid, which they identified to contain $7 \mathrm{~S}$ $\gamma \mathrm{G}$ rheumatoid factor after acid dissociation. These complexes precipitated with $\mathrm{Clq}$ and in a few instances demonstrated whole complement fixation. The presence of IgG aggregates in synovial fluid from patients with seronegative rheumatoid arthritis has also been confirmed in recent studies by Hurd, LoSpalluto, and Ziff (1970). These authors identified phagocytized IgG- $\beta_{1 c}$ inclusions in leucocytes after the addition of IgM rheumatoid factor to synovial fluid from seronegative rheumatoid patients.

Complement fixation using cryoprecipitable material detects the presence of aggregates in rheumatoid synovial fluid in a higher percentage of patients than has recently been reported using precipitation by rheumatoid factor or $\mathrm{Clq}$ in Ouchterlony double diffusion in agar (Britton and Schur, 1971). This may reflect the sensitivity of the complement-fixation method, which, in studies on fractionated cryoprecipitates, has demonstrated detection of as little as $5 \mu \mathrm{g}$. of IgG aggregates per $0.1 \mathrm{ml}$.

The origin of $\mathrm{IgG}$ aggregates in synovial fluid is not certain at the present time. Aggregation of IgG in rheumatoid synovial fluid might occur as a result of its combination with specific antigen (such as autologous IgG, an infectious agent, or cell breakdown product); or aggregation might occur as a result of a metabolically altered IgG because of abnormal synthesis or metabolism (Vaughan, Jacox, Abraham, and Clark, 1969).

The role of rheumatoid factor in the complement fixation may be complex. Zvaifler and Schur (1968) have reported complement fixation in the reaction of rheumatoid factor with aggregates of mercaptoethanol-treated IgG. Although earlier studies had shown that rheumatoid factor could inhibit complement fixation (Heimer, Levin, and Kahn, 1963), recent studies have demonstrated the enhancement of fixation by soluble complexes in certain conditions (Tesar and Schmid, 1970). Since IgG aggregates are 
capable of complement fixation, and since rheumatoid factor competes for the same sites on IgG which bind complement (Heimer and others, 1963), the relationship of these reactants in synovial fluid must be more precisely defined before final conclusions can be drawn regarding the participation of rheumatoid factor in the complement fixation observed in these studies. That rheumatoid factor may enhance complement fixation is suggested by greater amounts of complement-fixing activity observed in seropositive patients. However, rheumatoid factor could be present secondarily in response to the greater amount of IgG or IgG-antigen aggregate, and not directly involved in complement fixation.

Despite some uncertainties regarding the precise origin and constituents of the complement-fixing complexes in rheumatoid synovial fluid, it seems reasonable on the basis of present knowledge to postulate that these complexes are responsible for the depletion of complement. They contribute to the phagocytized material present in leucocytes and synovial lining cells, and to inflammation and tissue damage through the well-known biological activity of the complement mediator system (Osler, 1961; Cochrane, 1968). The association of complementfixing aggregates demonstrated in whole synovial fluid with severe destructive synovitis and seropositive rheumatoid arthritis, and of lesser amounts in patients with milder and seronegative disease, may be further indicative of a causal relationship to tissue damage. Alternatively, the larger amount of complementfixing activity might be a sequela of severe disease. The high incidence of complement-fixing activity discovered by the sensitive techniques described in both seropositive and seronegative patients suggests an important role for immune complexes in the pathogenesis of rheumatoid joint inflammation.

\section{Summary}

Complement-fixing activity was found in whole synovial fluid from 67 per cent. of seropositive rheumatoid, 12 per cent. of seronegative rheumatoid, and 2 per cent. of nonrheumatoid patients. Isolated synovial fluid cryoproteins demonstrated complement fixation in 97 per cent. of seropositive rheumatoid, and 9 per cent. of non-rheumatoid patients. The magnitude of complement fixation correlated with the severity of the arthritis and inversely with the complement titre. This activity consumes multiple components of the complement system in a manner analogous to complement fixation by antigenantibody complexes, and appears to be a major factor in the activation of the complement system in the rheumatoid joint. As such, it may have an important role in the pathogenesis of rheumatoid joint inflammation.

\section{References}

Barnett, E. V., Bluestone, R., Cracchiolo, A., Goldberg, L. S., Kantor, G. L., And McIntosh, R. M. (1970) Ann. intern. Med., 73, 95 (Cryoglobulinemia and disease)

Baumal, R., ANd Broder, I. (1968) Clin. exp. Immunol., 3, 555 (Studies into the occurrence of soluble antigen antibody complexes in disease. III. Rheumatoid arthritis and other human diseases)

Borsos, T., AND RAPP, H. J. (1967) J. Immunol., 99, 263 (Immune hemolysis: A simplified method for the preparation of EAC'4 with guinea pig or with human complement)

_- — - AND COOK, C. T. (1961a) 87, 330 (Studies on the second component of complement. III. Separation of the second component from guinea pig serum by chromatography on cellulose derivatives)

- - - AND MAYer, M. M. (1961b) Ibid., 87, 310 (Studies on the second component of complement. I. The reaction between $\mathrm{EAC}^{\prime} 1,4$, and $\mathrm{C}^{\prime} 2$. Evidence on the single site mechanism of immune hemolysis and determination of $\mathrm{C}^{\prime} 2$ on a molecular basis)

Britton, M. C., ANd Schur, P. H. (1971). Arthr. and Rheum., 14, 87 (The complement system in rheumatoid synovitis. II. Intracytoplasmic inclusions of immunoglobulin and complement)

Cochrane, C. G. (1968) J. Allergy, 42, 113 (The role of immune complexes and complement in tissue injury)

Fish, A. J., Michael, A. F., Gewurz, H., AND Good, R. A. (1966) Arthr. and Rheum., 9, 267 (Immunopathologic changes in rheumatoid arthritis synovium)

Fostiropoulos, G., Austen, K. F., AND Bloch, K. J. (1965) Ibid., 8, 219 (Total hemolytic complement and second component of complement activity in serum and synovial fluid)

HANnestad, K. (1967) Clin. exp. Immunol., 2, 511 (Presence of aggregated $\gamma \mathrm{G}$ globulin in certain rheumatoid synovial effusions)

Hedberg, H. (1963) Acta rheum. scand., 9, 165 (Studies on the depressed hemolytic complement activity of synovial fluid in adult rheumatoid arthritis)

- (1967) Acta med. scand., 479, Suppl., 1 (Studies on synovial fluid in arthritis. I. The total complement activity)

Heimer, R., Levin, F. M., AND KAHN, M. F. (1963) J. Immunol., 91, 866 (Inhibition of complement fixation by human serum. II. The activity of a $\gamma$-im globulin and rheumatoid factor in complement fixation reactions).

Hurd, E. R., LoSpalluto, J., AND ZIFf, M. (1970) Arthr. and Rheum., 13, 724 (Formation of leukocyte inclusions in normal polymorphonuclear cells incubated with synovial fluid) 
Kabat, E. A., AND MaYer, M. M. (1961) 'Experimental Immunochemistry', 2nd ed., p. 133. Thomas, Springfield, Ill.

Kaplan, M. H. (1963) In 'Proc. Amer. rheum. Ass.', Arthr. and Rheum., 6, 475 (Site of formation of rheumatoid factor, p. 467)

Marcus, R. L., AND Townes, A. S. (1971) J. clin. Invest., 50, 282 (The occurrence of cryoproteins in synovial fluid; the association of a complement-fixing activity in rheumatoid synovial fluid with cold-precipitable protein)

Müller-EberhaRd, H. J., AND BiRo, C. E. (1964) J. exp. Med., 118, 447 (Isolation and characterization of the fourth component of human complement)

Nelson, R. A., Jensen, J., Gigli, I., And Tamura, N. (1966) Immunochemistry, 3, 111 (Methods for the separation, purification and measurement of nine components of hemolytic complement in guinea-pig serum)

OsLeR, A. G. (1961) Functions of the complement system', in 'Advances in Immunology', vol. 1, p. 131. Academic Press, New York and London

Pekin, T. J., JR., AND ZvaIfLer, N. J. (1964) J. clin. Invest., 43, 1372 (Hemolytic complement in synovial fluid)

Peltier, A., Coste, F., ANd Delbarre, F. (1966) Presse méd., 74, 1523 (Études sur le complément hémolytique dans certaines maladies ostéo-articulaires. Résultats d'ensemble)

Rawson, A. J., Abelson, N. M., and Hollander, J. L. (1965) Ann. intern. Med., 62, 281 (Studies on the pathogenesis of rheumatoid joint inflammation. II. Intracytoplasmic particulate complexes in rheumatoid synovial fluids)

Rodman, W. S., Williams, R. C., Bilka, P. J., and Müller-Eberhard, H. U. J. Lab. clin. Med., 69, 141 (Immunofluorescent localization of the third and fourth component of complement in synovial tissue from patients with rheumatoid arthritis)

Ropes, M. S., Bennett, G. A., Cobb, S., Jacox, R., and Jessar, R. A. (1959) Ann. rheum. Dis., 18, 49 (1958 Revision of diagnostic criteria for rheumatoid arthritis)

RudDy, S., AND Austen, K. F. (1970) Arthr. and Rheum., 13, 713 (The complement system in rheumatoid synovitis. I. An analysis of complement component activities in rheumatoid synovial fluids)

- Britton, M. C., Schur, P. H., and Austen, K. F. (1969) Ann. N.Y. Acad. Sci., 168, 161 (Complement components in synovial fluid: Activation and fixation in seropositive rheumatoid arthritis)

Singer, J. M., AND Plotz, C. M. (1956) Amer. J. Med., 21, 888 (Latex fixation test. I. Application to the serologic diagnosis of rheumatoid arthritis)

Tesar, J. T., AND SCHMID, F. R. (1970) J. Immunol., 105, 1206 (Conversion of soluble immune complexes into complement-fixing aggregates by IgM rheumatoid factor)

Townes, A. S., AND SowA, J. M. (1970) Johns Hopk. med. J., 127, 23 (Complement in synovial fluid)

- AND STEWART, C. R., JR. (1965) Ibid., 117, 348 (Estimation of the second component and third component complex of complement in the serum of patients with systemic lupus erythematosus)

,-- , AND OsLeR, A. G. (1963) Ibid., 112, 202 (Immunologic studies of systematic lupus erythematosus. II. Variations of nucleoprotein-reactive gamma globulin and hemolytic serum complement with disease activity)

Vaughan, J. H., Barnett, E. V., Sobel, M. V., and Jacox, R. F. Arthr. and Rheum. 11, 125 (Intracytoplasmic inclusions in rheumatoid arthritis and other diseases)

- Jacox, R. F., Abraham, G., AND Clark, R. (1969) Ann. N.Y. Acad. Sci., 168, 111 (Relation of rheumatoid factor to intracellular inclusions)

,-- , AND Noell, P. (1968b) Arthr. and Rheum., 11, 135 (Relation of intracytoplasmic inclusions in joint fluid leukocytes to anti- $\gamma \mathbf{G}$ globulins)

Winchester, R. J., Agnello, V., AND Kunkel, H. G. (1969) Ann. N.Y. Acad. Sci., 168, 195 (The joint-fluid $\gamma \mathrm{G}$-globulin complexes and their relationship to intraarticular complement diminution)

ZVAIFLER, N. J., AND SCHUR, P. H. (1968) Arthr. and Rheum., 11, 532 (Reactions of aggregated mercaptoethanol treated gamma globulin with rheumatoid factor-Precipitin and complement fixation studies) 